Jacek Paulinek

Warszawa

\title{
Rola i znaczenie opisu formalnego druku dla badań księgoznawczych nad książką literacką pierwszej połowy XIX wieku ${ }^{1}$
}

„Dawna książka jest dokumentem przeszłości historycznej [...]. Podobnie jak dla badacza sztuki konieczne jest na pierwszym etapie roboczym zewidencjonowanie zabytków, tak też i dla badacza piśmiennictwa czy dziejów książki konieczne jest zarejestrowanie i wskazanie tych obiektów, które będą stanowiły źródło i przedmiot jego studiów"2.

W taki sposób w 1952 r. Alodia Kawecka-Gryczowa rozpoczęła swój przegląd dokonań księgoznawców po 1945 roku $^{3}$. W toku wywodu autorka stwierdza, że praca księgoznawcy i bibliografa to naturalne dopełnienie dyscyplin literaturoznawczych - wskazuje tu nazwiska Estreicherów, Kazimierza Piekarskiego i Tadeusza Mikulskiego. O ile takie stwierdzenie ma swoją egzemplifikację w badaniach nad starymi drukami, to w przypadku literackiej książki dziewiętnastowiecznej problematyka ta jest niestety jeszcze za mało rozwinięta, bowiem księgoznawcy i bibliotekoznawcy nie biorą z reguły udziału w tworzeniu historii literatury tego okresu. Za mało też starają się o wykazanie konieczności swojej aktywności na tym polu badawczym. Co więcej, książka XIX stulecia, nie tylko literacka, wydaje się pozostawać poza kręgiem zainteresowa-

\footnotetext{
${ }^{1}$ Pierwszą połowę XIX wieku definiuję jako okres od 1.01.1801 roku do 31.12.1863 roku, książkę polską zaś - jako polonicum w rozumieniu estreicherowskim.

${ }^{2}$ Alodia Kawecka-Gryczowa, Fragmenta, Wrocław 1952, s. 3. W podobny sposób problem widział Karol Estreicher: „,...] rzucono się do pisania historii literatury pierwej, zanim ostatecznie obrobiono bibliografia. Ostatnią traktowano obok literatury jakoby rzecz podrzędna, podporządkowaną. Budowy na tych podwalinach okazały się wątlymi [...]. Raz opracowany przedmiot ten w swej całości, będzie mógł na przyszłość służyć historiografom za materiał do budowania kombinacji i wniosków. Bez takiej podstawy wnioski są zawodne i obracające się w jednym kole szczupłych wiadomości” - Karol Estreicher, Bibliografia polska XIX stulecia, cz. I, t. I, Kraków 1870, s. XII.

${ }^{3}$ Chodzi o Zakład Starych Druków Biblioteki Narodowej i Pracownię Bibliografii Staropolskiej Instytutu Badań Literackich PAN.
} 
nia badaczy posługujących się metodą księgoznawczą. Przyczyn takiego stanu upatruję $\mathrm{w}$ strukturze organizacyjnej polskich bibliotek i instytucji decydujących o kształcie badań literackich w Polsce, a przede wszystkim - w metodzie opracowania formalnego druków tego okresu.

$\mathrm{Na}$ początku XXI w. bibliotekarze traktują książkę dziewiętnastowieczną na równi ze współczesną. Oprócz oczywistych różnic morfologicznych między nimi, wynikających ze sposobu wytwarzania, trzeba też pamiętać, że książka dziewiętnastowieczna nie ma już dzisiaj wartości użytkowej (w takim sensie jak współczesna), a w świadomości przeciętnego człowieka druk z roku 1850 jest „starodrukiem”. Jednakże osoby wyznaczające kierunki polityki bibliotecznej zdają się nie zauważać problemu, wtłaczając książkę dziewiętnastowieczną w sztywne ramy systematyzacji, opisu i zasad przechowywania właściwych dla standaryzowanej książki współczesnej. Takie działania obecnie nie mają już żadnego uzasadnienia ${ }^{4}$. Książka ta stanowi obecnie często rzadkość, a „duży procent druków XIX wieku znany nam jest jedynie z tytułów. Nieraz poszukiwanie po wszystkich bibliotekach polskich jakiegoś interesującego dzieła z XIX w. nie daje rezultatu. Dzieło jest stracone [...]"5.

We wszystkich dyscyplinach wiedzy dokumentujących wytwory kultury materialnej specjalnej ochronie, rejestracji i opisowi podlegają obiekty unikatowe bądź zachowane w niewielkiej liczbie egzemplarzy. Jest tak i w bibliologii. Jeżeli miarą poziomu zabezpieczenia i szczegółowości opisu ma być rzadkość występujących egzemplarzy, to w Polsce nie jesteśmy w tej kwestii konsekwentni. Przytoczone powyżej słowa Karola Estreichera (wnuka) o skromnym stanie zbiorów książki dziewiętnastowiecznej odnoszą się w szczególności do polskojęzycznej książki literackiej, publicystycznej i popularnej, czyli takiej, która na skutek dużego popytu szybko ulegała zaczytaniu ${ }^{6}$. Tymczasem w odniesieniu do rzadkich druków dziewiętnastowiecznych stosuje się te same schematyczne metody opisu (format MARC21 dla książki ${ }^{7}$ ), co dla druków współczesnych. Trudno,

${ }^{4}$ Nawiązuję do okresu powojennego, kiedy najważniejsze zadanie stanowiło szybkie zinwentaryzowanie, opracowanie i udostępnienie zbiorów publicznych. $Z$ tego powodu istotne było jak najprostsze usystematyzowanie kolekcji bibliotecznych.

${ }^{5}$ K. Estreicher, Bibliografia polska XIX stulecia, wyd. II, t. 1, Kraków 1959, s. LV.

${ }^{6}$ Polska produkcja wydawnicza w pierwszej połowie XIX wieku, podobnie jak W stuleciach wcześniejszych, pełniła funkcję uzupełniającą import książki obcej. Jak można wnioskować na podstawie Bibliografii polskiej, stan taki utrzymywał się do okresu po powstaniu styczniowym, kiedy to wydawnictwa znalazły szeroką rzeszę odbiorców w - znacznie powiększonej liczebnie przez represje popowstaniowe - inteligencji.

${ }_{7}$ Format MARC 21 rekordu bibliograficznego dla ksiażki, wyd. 3 zmienione i poprawione, oprac. zespół pod red. Kamili Grzędzińskiej, Warszawa 2012 [http://centrum. 
aby taki system opracowania bibliotecznego, nastawiony na rejestrację (bo uwzględniający tylko podstawowe elementy pola opisu bibliograficznego) i efektywność (czyli na liczbę rekordów wprowadzanych przez bibliotekarza) mógł przyczynić się do rozwoju naszej wiedzy na temat cech wydawniczych katalogowanych druków, a w połączeniu z opisem cech nabytych egzemplarzy - także dziejów bibliotek, czytelnictwa, obrotu książką czy rzemiosła artystycznego (introligatorstwa, zdobnictwa). Co więcej, zdarza się, że te procedury w przypadku książki XIX wieku nie spełniają nawet tak podstawowej funkcji, jak rozróżnienie wydań.

Mimo upływu 144 lat od publikacji pierwszego tomu (i 55 lat od ukazania się pierwszego tomu drugiego wydania), Bibliografia polska Estreicherów ${ }^{8}$ pozostaje do dzisiaj podstawowym źródłem bibliograficznym do badań nad dziewiętnastowieczną książką polską. W zakresie książki literackiej uzupełniaja ją Literatura polska Gabriela Korbuta ${ }^{9}$, Bibliografia literatury polskiej „,Nowy Korbut” (wyd. 1963-) ${ }^{10}$ oraz kompendium Dawni pisarze polscy (wyd. 2000-2004) ${ }^{11}$. Tylko pierwsza pozycja jest bibliografia sensu stricto. Pozostałe stanowią przewodniki biobibliograficzne po literaturze polskiej. O Bibliografii polskiej napisano już bardzo wiele $^{12}$, dlatego ograniczę się tylko do kwestii związanych z interesującym nas problemem opisu bibliograficznego. Wielką zasługą K. Estreichera było - obowiązujące do dzisiaj - ustalenie kolejności elementów opisu bibliograficznego. Uczony ten jako pierwszy wprowadził w polskim piśmiennictwie układ abecadłowy bibliografii z hasłem jako elementem szeregującym opisy bibliograficzne. Sam autor wypowiedział się w tej kwestii najpełniej: „ułożyłem zatem katalog druków, nie wdając się w opisy szczegółowe. Opisy takie pozostawiam specjalnym monografistom”"13, a dalej: ,autor ograniczył się do zarejestrowania druków,

nukat.edu.pl/images/stories/file/instrukcje_procedury/MARC_21/marc21ksiazka_www. pdf] (15.03.2014).

${ }^{8}$ Zob. K. Estreicher, Bibliografia polska XIX stulecia, wyd. I, Kraków 1870-1916 (wyd. II, Kraków 1959 -).

${ }^{9}$ Zob. Gabriel Korbut, Literatura polska od poczatków do powstania styczniowego. Ksiażka podręczna informacyjna dla studiujacych naukowo dzieje rozwoju piśmiennictwa polskiego, wyd. I, t. 1-3, Warszawa 1917-1921 (wyd. II powiększ., t. 1-4, Warszawa 1929-1931).

${ }^{10}$ Zob. Bibliografia literatury polskiej „Nowy Korbut”, red. Kazimierz Budzyk i in., [Warszawa] 1963-.

${ }^{11}$ Zob. Dawni pisarze polscy od poczatków piśmiennictwa do Młodej Polski. Przewodnik biograficzny i bibliograficzny, [koordynacja całości Roman Loth], t. 1-5, Warszawa 2000-2004.

${ }_{12}$ Zob. np. Maria Dembowska, Metoda Bibliografii polskiej Karola Estreichera, wyd. II rozszerzone i uzupełnione, Warszawa 1970.

${ }^{13} \mathrm{~K}$. Estreicher, Bibliografia polska XIX stulecia, cz. 1, t. 1, s. XII. 
bez wdawania się w rozumowania. Druki jednakowoż opisane są z możliwą dokładnością, w miarę jak autor miał je w ręku. Tytuł dzieła w całości dosłownie powtórzony, liczba stronic i rycin podana [...]"14. Drugie wydanie nie zmieniło $\mathrm{w}$ tym względzie zbyt wiele: „Obecne wydanie Bibliografii polskiej XIX wieku jest tylko odnowieniem dzieła" ${ }^{15}$. W zamierzeniu twórcy Bibliografia polska miała być w pierwszej kolejności katalogiem księgarskim i bibliotecznym ${ }^{16}$, dlatego zastosowany opis bibliograficzny ograniczał się do podstawowych danych identyfikujących tekst, niekoniecznie - wydanie.

Ukazanie się w 1917 r. pierwszego tomu Literatury polskiej G. Korbuta wprowadziło nową jakość do badań nad polskim piśmiennictwem. W zamierzeniu autora książka miała być ,,podręcznikiem informacyjnym, przeznaczonym dla studiujących naukowo dzieje rozwoju piśmiennictwa polskiego [...]"'17. W przewodniku stanowiącym połączenie słownika biograficznego pisarzy polskich z bibliografią literatury polskiej uczony zastosował trójdzielność konstrukcji hasła (zawierającego biogram, bibliografię podmiotową i przedmiotowa) $\mathrm{w}$ połączeniu $\mathrm{z}$ faktograficzna opisowością notki biograficznej i zwięzłością opisu bibliograficznego. Przy porządkowaniu materiału wykorzystał układ chronologiczny ${ }^{18}$.

Główna cecha Literatury polskiej to selektywność w wyborze materiału, co jest zrozumiałe ze względu na zakres chronologiczny opracowania. Przy wyborze twórców G. Korbut nie kierował się rodzajem uprawianej przez nich działalności pisarskiej, stąd uwzględnieni zostali nie tylko przedstawiciele literatury pięknej, lecz także nauki czy kultury. Z wydań dzieł uczony uwzględnił tylko pierwodruki i wydania krytyczne oraz najpełniejsze. W bibliografii przedmiotowej obok rozpraw naukowych znajdują się również artykuły napisane przez niespecjalistów.

W oparciu o metodę stosowana przez G. Korbuta powstały dwie prace, również ważne dla historyka książki literackiej XIX w. Przyjęto w nich

\footnotetext{
${ }^{14}$ Tamże, s. XV.

${ }^{15} \mathrm{~K}$. Estreicher, Bibliografia polska XIX stulecia, wyd. II, t. 1, s. LI.

16 „Nie szło o dzieje, o rozumowanie, ale o katalog - to jest: o katalog księgarski i biblioteczny" - K. Estreicher, Bibliografia polska XIX stulecia, cz. 1, t. 1, s. XV.

${ }^{17}$ G. Korbut, Literatura polska od poczatków..., t. 1, Warszawa 1929, s. V.

18 Podobne zamierzenia miał pierwotnie K. Estreicher. We wstępie do pierwszego tomu czytamy: „Zrazu zamierzałem dołączyć biografie autorów, ich prace po czasopismach, i rękopiśmienne, w sposób jak to Jungmann uczynił. W toku atoli gromadzenia materiałów przekonałem się, że względy te rozliczne nie dadzą się pogodzić. Tak formowana księga urosłaby do rozmiarów, które by uniemożebniły druk dzieła. Biografie więc, ocenienie pism i treść czasopism zachowałem $\mathrm{w}$ tece, a nawet $\mathrm{w}$ następności zmiany planu, zarzuciłem studia w tym kierunku" (K. Estreicher, Bibliografia polska XIX stulecia, cz. 1, t. 1, s. XII).
} 
podobne założenia dotyczące selekcji materiału i skrótowości opisu bibliograficznego. O ile seria „Nowy Korbut” - na co wskazuje treść i sposób opracowania - została przygotowana z myślą o naukowcach, to przewodnik Dawni pisarze polscy ma stanowić ,podręczne, funkcjonalne kompendium z dziedziny historii literatury polskiej, mogące służyć powszechnie dostępną i aktualną informacją" "19. Największą zaletą obydwu publikacji jest uporządkowanie materiału (w zakresie większym niż zrobił to K. Estreicher), poprzez wskazanie dzieł rozpowszechnianych pod różnymi tytułami.

Przyjrzyjmy się, jak wygląda opis tego samego wydania w wymienionych wyżej publikacjach (poza Literatura polska G. Korbuta, który wymienia - zgodnie z założeniami - tylko wydanie zbiorowe i krytyczne).

Bibliografia polska, wydanie pierwsze:

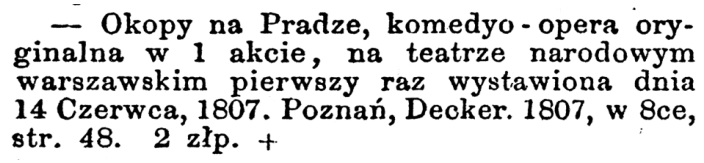

Bibliografia polska, wydanie drugie:

- Okopy na Pradze. Komedyo-opera oryginalna w 1 akcie, na Teatrze Narodowym Warszawskim pierwszy raz wystawiona dnia 14 Czerwca 1807. Poznań, Decker, 1807, w 8ce, str. 48 , zlp. 2.

$$
\text { Ak. - Inst.Bad.Lit. - Jag. - Nar. }-\overline{\text { Pozn. Un. }}
$$

„Nowy Korbut":

12. Okopy na Pradze. Komedioopera oryginalna w 1 akcie. Wyst. W-wa 14 czerwca 1807. Wyd. Poz. 1807. Wyd. nast.: Poz. 1905; Poz. 1926 Naród sobie! Piosenki wyd.: Gaz. Warsz. $1807 \mathrm{nr} 48$ Dod.; Spiewki z komedioopery ,Okopy na Pradze", napisanej roku 1807. B.m.r.; zob. poz. 109 t. 4. (Muzyka J. Stefaniego z „Krakowiaków i górali”).

Stosownie do okoliczności Dmuszewski zmienial te komedie i wystawial pod różnymi tytulami. Zob. poz. 19, 22.

Źródło franc. nieznane.

Dawni pisarze polscy:

8. Okopy na Pradze. Komedioopera oryginalna w 1 a. Wyst. Wwa 1807. Wyd. Pozn. 1807. Wyd. nast.: Pozn. 1905; Pozn. 1926. (Muzyka J. Stefani z „Krakowiaków i Górali”).

${ }^{19}$ Dawni pisarze polscy..., t. 1, Warszawa 2000, s. 5. 
Następne, zmieniane stosownie do okoliczności wersje sztuki: Pożegnanie, czyli marsz wojowników (1808); Przygotowanie na przyjęcie wojska polskiego w Krakowie (1809).

Poniżej dla porównania opis z katalogu centralnego NUKAT (wykonany w 2012 roku):

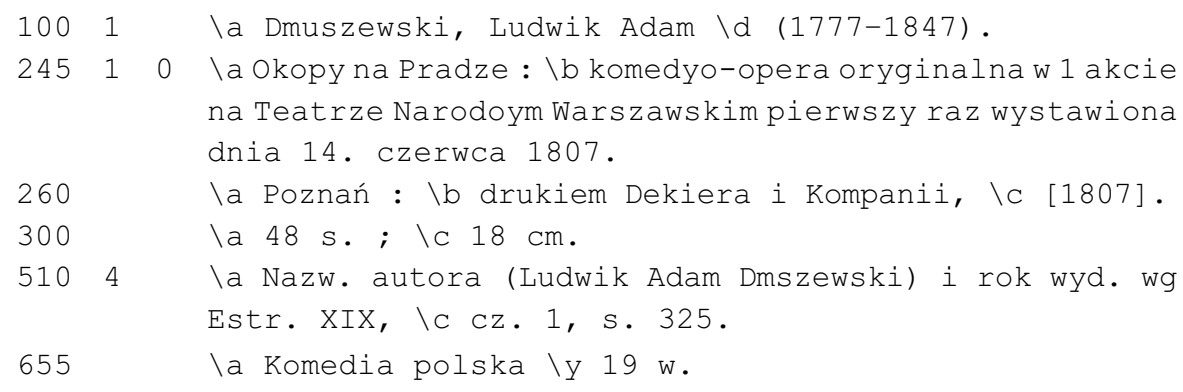

Wspólny dla wszystkich przykładów jest rejestracyjny model opisu bibliograficznego. W przypadku opisów zaczerpniętych ze źródeł drukowanych widać ich charakterystyczne cechy. I tak w pierwszym wydaniu Bibliografii polskiej uwzględniono podstawowe elementy opisu: dokładnie odpisany tytuł, miejsce wydania, wydawcę, rok wydania, format, objętość i cenę. W drugim wydaniu powtórzono zasadniczo wszystkie dane - poddano je jedynie kosmetycznym zabiegom i dołączono wykaz bibliotek posiadających egzemplarze danego druku. W „Nowym Korbucie" skrócono tytuł, uwspółcześniono jego pisownię i usunięto nazwę wydawcy, za to dołączono informacje o kolejnych edycjach i przeróbkach tekstu występujących pod innymi tytułami. W Dawnych pisarzach polskich powielono informacje $\mathrm{z}$ „Nowego Korbuta” (tytuł uległ tu jeszcze większemu skróceniu). Założeniem Estreicherów była „tylko” rejestracja druków - można by więc oczekiwać, że współcześnie prace zmierzają ku nadrobieniu zaległości i uzupełnieniu opisów o bardziej szczegółowe dane. Jak widać na powyższym przykładzie, opis nukatowski ogranicza się jednak do dostosowania opisu K. Estreichera do potrzeb katalogu komputerowego i formatu MARC21. Ma to swoje konsekwencje.

Poniżej (Il. 1) zreprodukowano kartę tytułową edycji stanowiącego podstawę opisu nukatowskiego.

Ludwik Adam Dmuszewski (1777-1847) był aktorem, reżyserem, autorem sztuk i barwną postacią warszawskiego życia towarzyskiego i kulturalnego w pierwszej połowie XIX stulecia. Zapewne popularność artysty powodowała, że chętnie kopiowano wydania jego tekstów (Il. 2, Il. 3) 


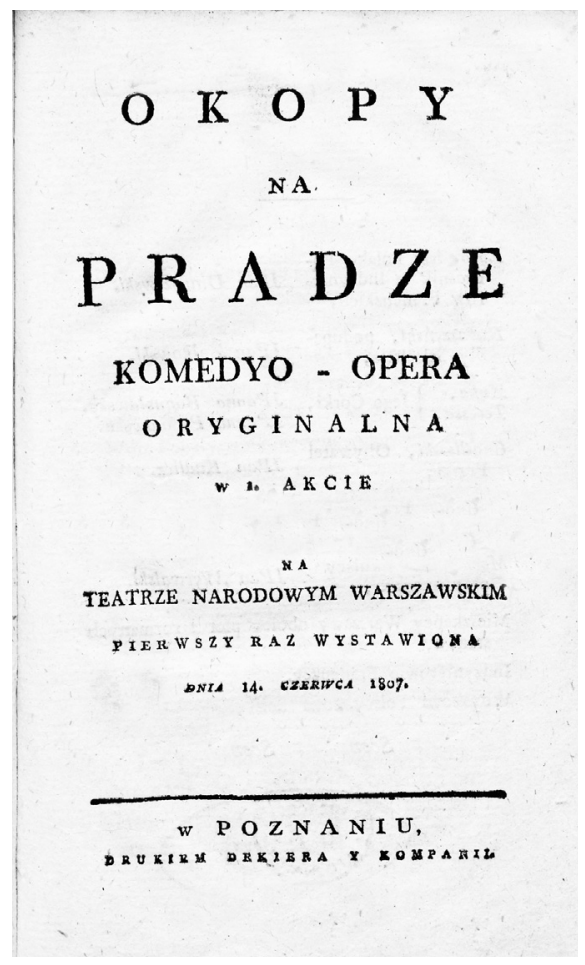

O S O B Y:

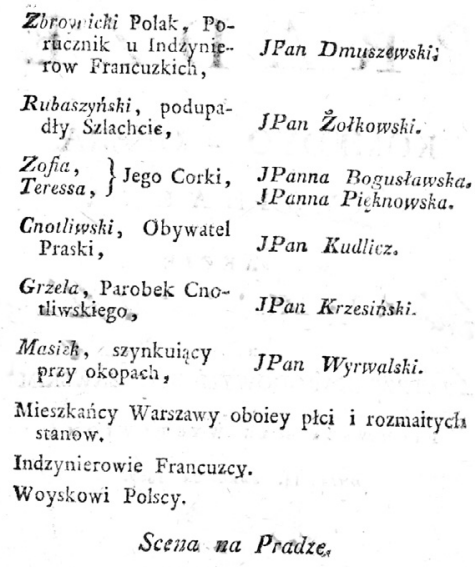

Il. 1. Ludwik Adam Dmuszewski, Okopy na Pradze, komedyo-opera oryginalna w 1. akcie na Teatrze Narodowym Warszawskim pierwszy raz wystawiona dnia 14. czerwca 1807, [Ed.A], W Poznaniu, [1807]. Karta tytułowa (recto/verso).

Prawdopodobnie dwie z prezentowanych edycji (lub wszystkie trzy) są wydaniami korsarskimi. Powielanie popularnych książek w taki sposób, aby stworzyć iluzję, że są to te same wydania, które służyły za podstawę przedruku, jest zapewne tak stare jak rzemiosło drukarskie, a przedstawione przykłady dowodzą biegłego opanowania przez drukarzy zasad tego procederu. Jednak kopii bardzo trudnych do odróżnienia od oryginału prawie się nie spotyka. Najprostsza metoda polega oczywiście na porównywaniu egzemplarzy. Przy zestawieniu bliskich sobie wydań zazwyczaj już na pierwszy rzut oka widać różnice w stopniu i kroju pisma na karcie tytułowej i w tekście, jego podziale na wiersze, położeniu sygnatur itd. W naszym wypadku mamy zatem trzy wydania tego samego tekstu - o tym samym tytule, adresie wydawniczym i objętości. Równocześnie nie mamy pewności, czy którykolwiek z druków został wytłoczony na prasach Deckera w Poznaniu. Hipotetycznie rzecz biorąc, następnym naszym zadaniem byłoby porównanie wydań z innymi zacho- 


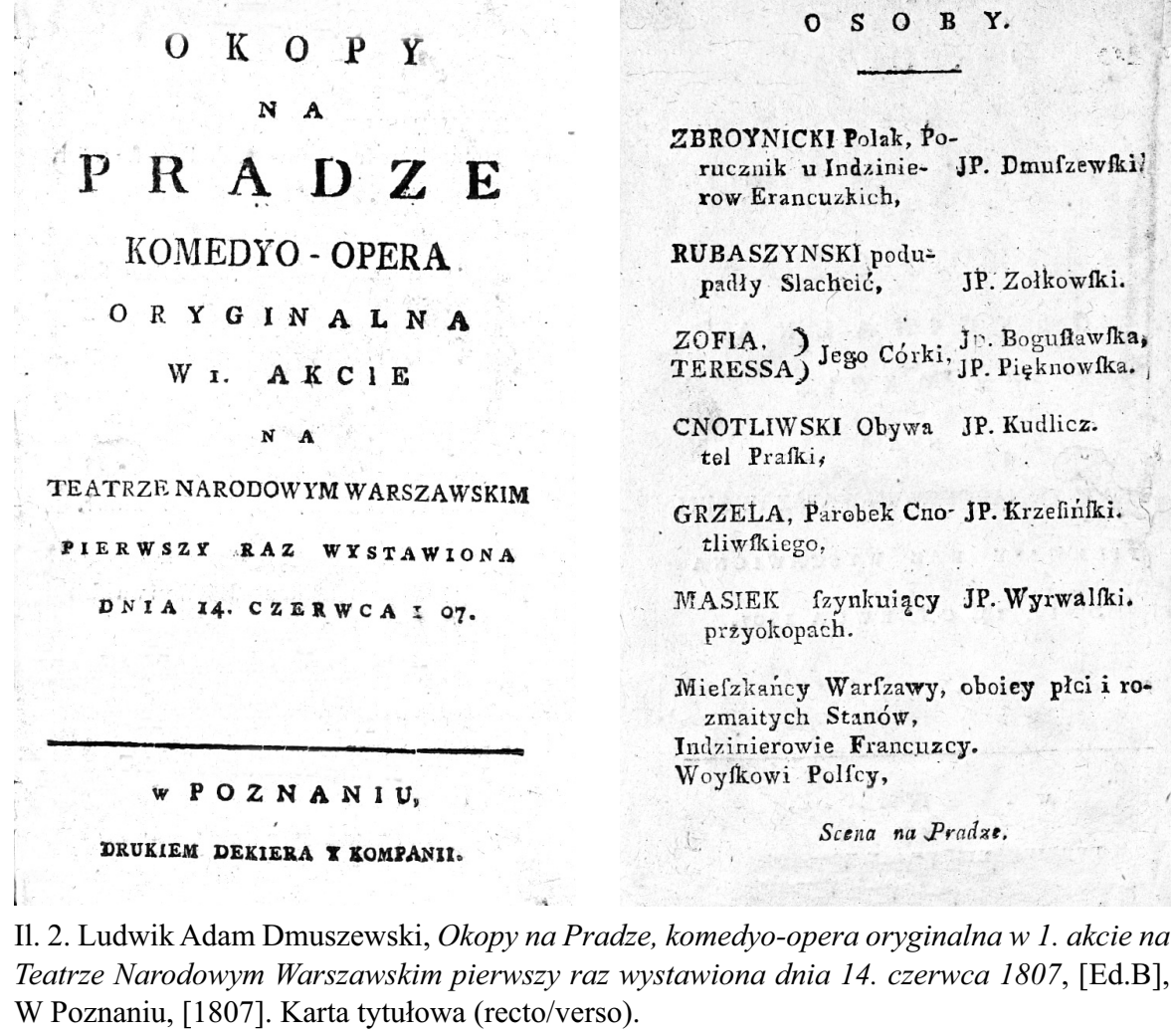

O

N A

P R A D Z E

KOMEDYO - OPERA

O R Y G I N A L N A

$W$ I. A K C I E

N A

TEATRZE NARODOWYM WARSZAWSKIM

PIERWSZX RAZ WISTAWIONA

D'IA I4. CZERWCA I ०7.

W POZNANIU,

DRUKLEM DEKIERA I ROMPANIR.

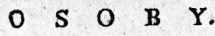

ZBROYNICKI Polak, Po-

rucznik u Indzinie- JP. Dmufzewfki? row Erancuzkich,

RUBASZYNSKI podu= padty Slachicic, JP. Zolkowiki.

ZOFIA, S Jego Córki, Ju. Boguflawfka,
TERESSA Pięknowfka.

CNOTLIWSKI Obywa JP. Kudlicz. tel Prafki,

GRZELA, Parobek Cno-JP. Krzefińiki. tliwflkiego,

MiASIEK fzynkuiący JP. Wyrwalfki. przyokopach.

Mielakanicy Warfzawy, oboiey płci i rozmaitych Stanów,

Indzinierowie Francuzcy.

Woyfkowi Polfcy,

$$
\text { Scena na Pradze. }
$$

I1. 2. Ludwik Adam Dmuszewski, Okopy na Pradze, komedyo-opera oryginalna w 1. akcie na Teatrze Narodowym Warszawskim pierwszy raz wystawiona dnia 14. czerwca 1807, [Ed.B], W Poznaniu, [1807]. Karta tytułowa (recto/verso).

wanymi w bibliotekach egzemplarzami, a w dalszej kolejności - znalezienie pierwszego z nich oraz ustalenie chronologii i filiacji poszczególnych edycji. Rozszyfrowanie rzeczywistego miejsca druku wymagałoby ponadto dokładnej analizy typograficznej oraz odwołania się do materiałów archiwalnych. Byłoby to bardzo trudne, ale pewnie nie niemożliwe. Ale co zrobić w przypadku, gdy nie mamy możliwości porównania egzemplarzy? W takich sytuacjach powinien nam pomóc odpowiednio rozbudowany schemat opisu bibliograficznego, który dawałby możliwość identyfikacji bez koniecznej i kłopotliwej porównawczej autopsji innych egzemplarzy dzieła. Pomimo że Estreicher przywiązywał wielką wagę do szczegółowości opisu bibliograficznego (podkreślał konieczność podawania pełnych tytułów dzieł i dokładnego opisywania cech fizycznych dokumentów), nie da się tego dokonać w oparciu o Bibliografię polska. Z kolei w katalogach bibliotek polskich w stosunku do druków XIX wieku stosuje się zbyt wielką oszczędność w opisach, co pozwala wpraw- 


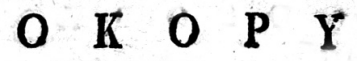 \\ NA

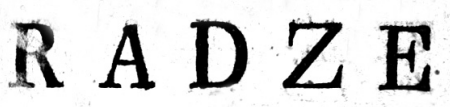

KOMEDYO - OPERA

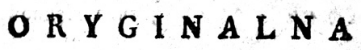

W I. AKCIE

NA

TEATRZE NARODOWYM WARSZAWSKTM

BIBRWSZTEAZWYSTAWTONA

DNIA 14. CZBRWCA 1807

- P O Z N A N I U.

DRUKIEM DEKIERA Y KOMPANIT

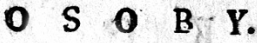

ZBROYNICKI Polak, Po-

sucznik \& Indzynierów JPan Denufzewiki.

Francuzkīel,

RUBASZYNSKL podupa-

diy Sulachcic,

JPan Żełkow Ri

ZorIA,
TiRR BSSA Jego Córki JPanna Bogufaw Jka,

CNOTLIWSKI Obywa- JPan Kudlic2. tel Prafki,

GRZELA, Parobek Cno-m JPan Krzesińfi, tliw kiego,

MASIEK szynkuiący przy JPan Wyrwalki okopach.

Miefzkańcy Warfzawy, oboiey plcî i rozmaitych Stanúw.

Mrdzynikrowie Francuzcy.

Woyflowi Polscy.

\section{Scena na Pradze.}

Il. 3. Ludwik Adam Dmuszewski, Okopy na Pradze, komedyo-opera oryginalna w 1. akcie na Teatrze Narodowym Warszawskim pierwszy raz wystawiona dnia 14. czerwca 1807, [Ed.C], W Poznaniu, [1807]. Karta tytułowa (recto/verso).

dzie na szybkie publikowanie materiału, ale budzi poważne zastrzeżenie, jeżeli chodzi o możliwość rozróżnienia dwóch podobnych edycji lub wariantów tego samego dzieła. Uważam, że do opisu książki jako jednostki wydawniczej w przypadku dziewiętnastowiecznych druków nie wystarczy stosowany obecnie sztywny schemat. Technika wytwarzania druków w XIX w. ulegała stałym przeobrażeniom, a podobieństwa i różnice między wydaniami nie są ilościowo i jakościowo stale te same, należy więc stosować zmienne metody opisu. Najprostszym i zarazem najlogiczniejszym rozwiązaniem byłoby użycie przy opisie druków XIX w. niektórych rozwiązań wykorzystywanych w przypadku druków starych ${ }^{20}$. Proszę mnie źle nie zrozumieć, nie dążę do tego, by dokonywać rewolucji i wprowadzać nowe obligatoryjne zasady opisu bibliograficznego dla

${ }^{20}$ Zob. Format MARC 21 rekordu bibliograficznego dla starych druków, oprac. Halina Mieczkowska, Warszawa 2007 - http://centrum.nukat.edu.pl/images/stories/file/instrukcje_procedury/MARC_21/marc21_staredruki_130711.pdf [15.03.2014]. 
druków XIX wieku. Zapewne i tak kiedyś to nastapi, ale obecnie chodzi o to, by umożliwić bibliotekarzom właściwe opracowanie zasobów, danie potrzebnych do tego celu narzędzi, których nie zapewniają obecne metody opisu. Format służący do opisu starego druku bez większych problemów można dostosować do potrzeb publikacji XIX wieku, ponieważ nawet do lat trzydziestych tego stulecia stosowano na naszym terenie podobne metody produkcji książki jak w XVIII wieku.

Jeśli przyjmiemy takie założenie, można zaproponować bardzo prosty sposób rozróżniania wydań - za pomocą kollacji, położenia sygnatur bądź fingerprintu ${ }^{21}$ (oczywiście nie ma potrzeby równoczesnego stosowania tych metod, wystarcza już jedna z nich):

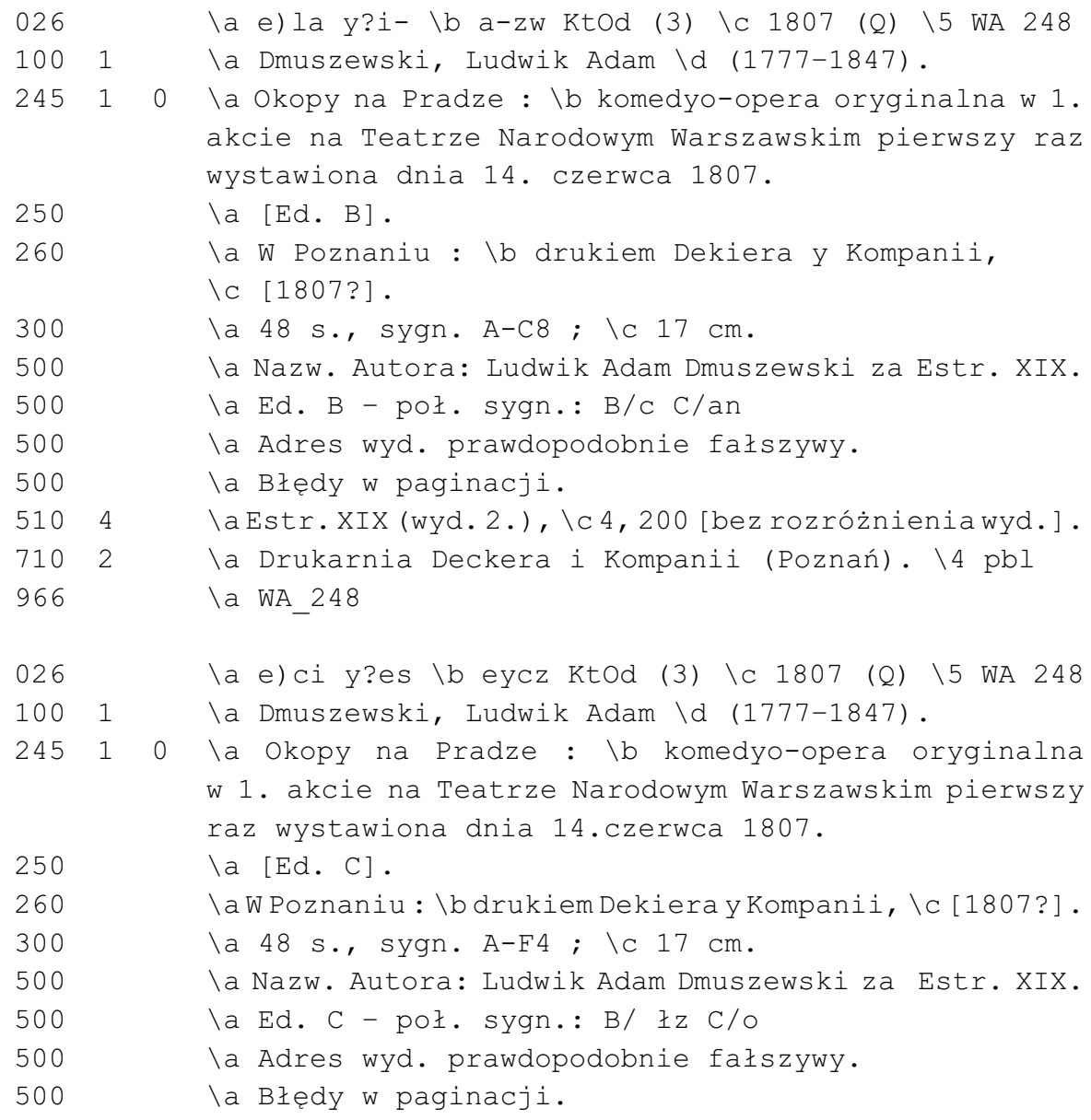

\footnotetext{
${ }^{21}$ Dwie pierwsze metody (kollację i opis położenia sygnatur) można zastosować w zasadzie tylko przy oglądzie książki drukowanej ręcznie na papierze czerpanym.
} 
Rola i znaczenie opisu formalnego druku dla badań księgoznawczych nad książką...

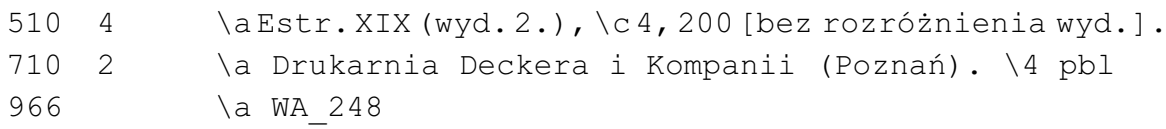

Uważam, że w odniesieniu do najstarszych druków XIX w. powinno się stosować większość zasad przyjętych do opisywania druków starych. Szczególną uwagę należy przywiązywać do właściwego odpisania tytułu i adresu wydawniczego ( $w$ formie gramatycznej występującej na dokumencie, a nie w mianowniku jak w przypadku druków współczesnych) oraz zawartości. Mam tu na myśli dedykacje, kolofon, listy subskrybentów i dzieła współwydane (a zwłaszcza katalogi księgarskie).

Ktoś może powiedzieć, że wprowadzenie takiego zamieszania z powodu jednego opisanego przypadku mija się z celem. To prawda, ale podobnych przykładów jest więcej. Oto dowód.

\section{POSPOTLTHE \\ R US Z ENIE}

KOMEDYO-OPERA

w DWOCH AKTACH.

Wystawiona pierwszy raz na Teatrze

Narodowym Warszawskim

Dnia i Maia 1807 .

W W A R S A W E.

W Drukarniach polączonych GazeTY WARszawskiey i Sukcessorów Tomasaa Le Bnun.

\section{O S O B Y.}

Pan Sztatingrumer przeszly

Justye-Rath - JPan Zolkowski.

FrYDenYK ( JPan Szymanowsǩk

Emilia (iego dzieci JPani Dmuszewska.

BRowiưs Kreis-Rychter, na-

rzeczony Emilii. JPan Zielinski.

Poczcriwsk Ekonom -. JPan Kudlicz.

Kazminenz Syn iego - JPan Dmuszewski.

KnXstyan ) JFan Koch.

Joнам służący Sztein- JPan Krzesinski.

Lizeta' ' brumera. JPani Zieliniska.

Rrcenstwo Pospolitego Ruszenia z Woiewodztwa Mazowieckiego.

Goścıe z sąsiedztwa plci oboiey.

Kozacy.

Scena w Ziemi Ciechanowskiey.

Rzecz się dzieie W.Mcu Grudniu 1806.

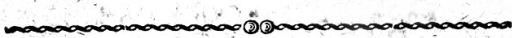

Teatr zoystawia Sale śrzodkowg miešika. nia Pana Szteinbrumera.

Il. 4. Ludwik Adam Dmuszewski, Pospolite ruszenie, komedyo-opera w dwóch aktach, wystawiona pierwszy raz na Teatrze Narodowym Warszawskim dnia 1 maia 1807, [Ed.A], W Warszawie, [1807]. Karta tytułowa (recto/verso). 
TPOSTOTITTE

\section{$\mathbb{R} U S Z \mathbb{E} \mathbb{N} \mathbb{H}$}

KOMEDYO-OPERA

w DWOCH AKTAET:

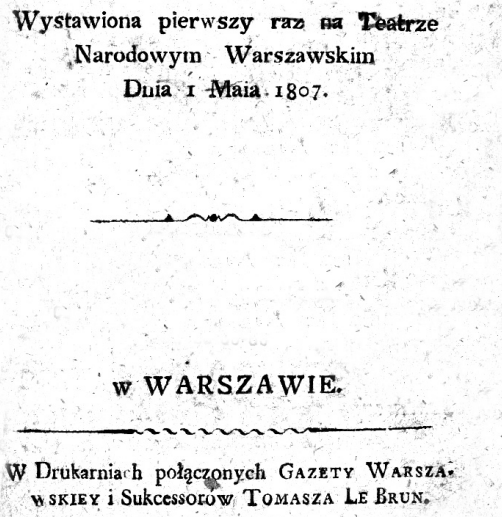

\section{O S O B Y.}

Pan Szteinbrumer przeszly

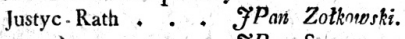

FRYDERYK ( FPan Szymanouski.

Emilia

Browius Kreis - Rychter, na.

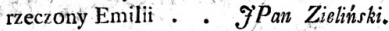

Poczciwsḱ Ekonom : GPan Kudlicz.

Kazimierz Syh iego - ·Pan Dinuszewski.

Krystyañ służacy Sztein. ЭPam Kock.

JонаN służący Sztein. ЭPan Krzeciński,

Lrzeta J brumera J̈Pani Zielińska.

RycERSTwo Pospolitego Ruszenia z Woiewodz: twa Mazowieczkiego.

Goście z sąsiedztwa płci oboiey.

Kozacr.

Scena w Ziemi Ciechanowskiey.

Rzecz fię dzieie w Mcu Grudniu 1806.

Teatr wystania Sate śrzadkoniq mieszkania Pana Szteinbrumera.

Il. 5. Ludwik Adam Dmuszewski, Pospolite ruszenie, komedyo-opera w dwóch aktach, wystawiona pierwszy raz na Teatrze Narodowym Warszawskim dnia 1 maia 1807, [Ed.B], W Warszawie, [1807]. Karta tytułowa (recto/verso).

Opisy w źródłach drukowanych:

Bibliografia polska, wydanie pierwsze:

- Pospolite ruszenie, komedyo-opera w 2 aktach wystawiona 1szy raz na teatrze warszawskim d. 1 Maja 1807. B, w. m. dr. i r., w 8ce, str. 61 .

- Toż. Warszawa, druk połącz. drukarni Gaz. War. i Lebrun, 1807, w 8ce, str. 57. 2 zlp.

Bibliografia polska, wydanie drugie:

- Pospolite ruszenie. Komedyo-opera w dwoch aktach. Wystawiona pierwszy raz na Teatrze Narodowym Warszawskim Dnia 1 Maia 1807. Warszawa, w Drukarniach połączonych Gazet Warszawskiej i Sukcesorów Tomasza Le Brun, b. r., w 8ce, str. 4 nl., 57, 3 nl., złp. 2. 
Rola i znaczenie opisu formalnego druku dla badań księgoznawczych nad książką...

Dedykowane Janowi hr. Ossolińskiemu.

Czy istnieje edycja b. m. i r. o 61 stronach?

Inst.Bad.Lit. - Nar. - Pozn.TPN -
Pozn.Un.

„Nowy Korbut”:

11. Pospolite ruszenie, czyli bitwa $z$ Kozakami. Komedioopera w 2 aktach. Wyst. W-wa 1 maja 1807. Wyd. W-wa (1807, dwa wyd.). Wyd. nast. W-wa 1809; W-wa 1813.

Dawni pisarze polscy: Dla porównania opis z katalogu centralnego

9. Pospolite ruszenie, czyli bitwa z Kozakami.

Komedioopera w 2 a. Wyst. i wyd. Wwa 1807

(dwa wyd.). Wyd. nast.: Wwa 1809; Wwa 1813

(muzyka J. Elsner).

NUKAT (wykonany w 2012 roku):

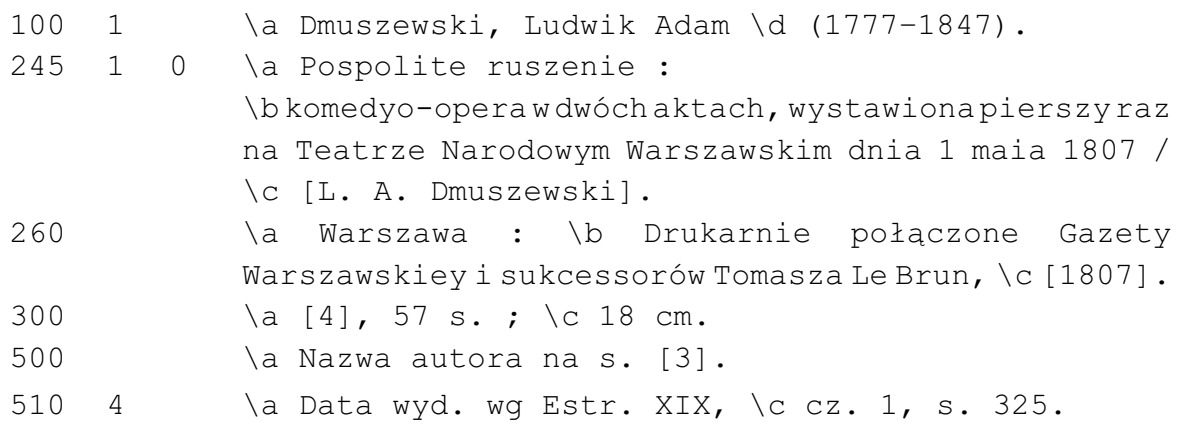

Poniżej znajdują się opisy przygotowane przeze mnie (Ed. A odpowiada opisowi nukatowskiemu):

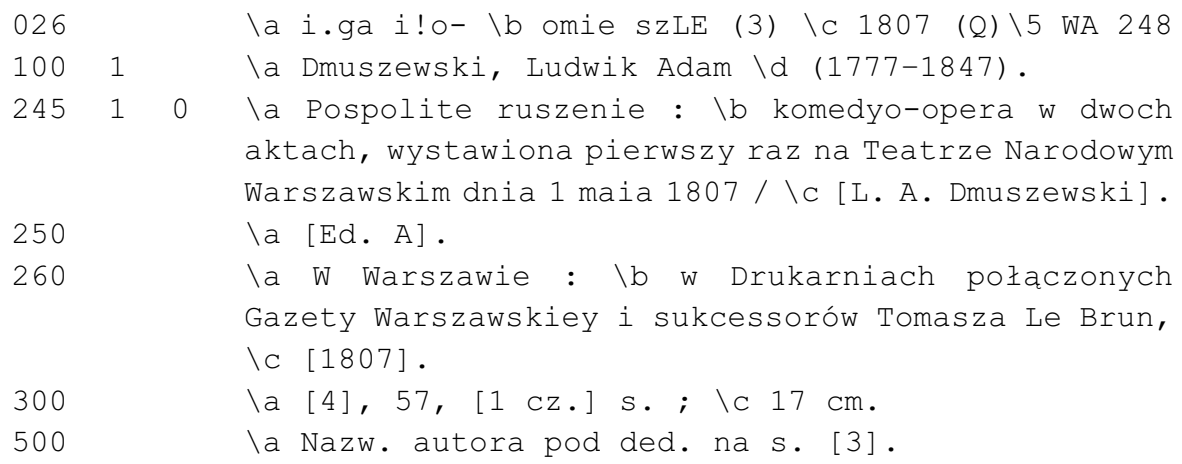




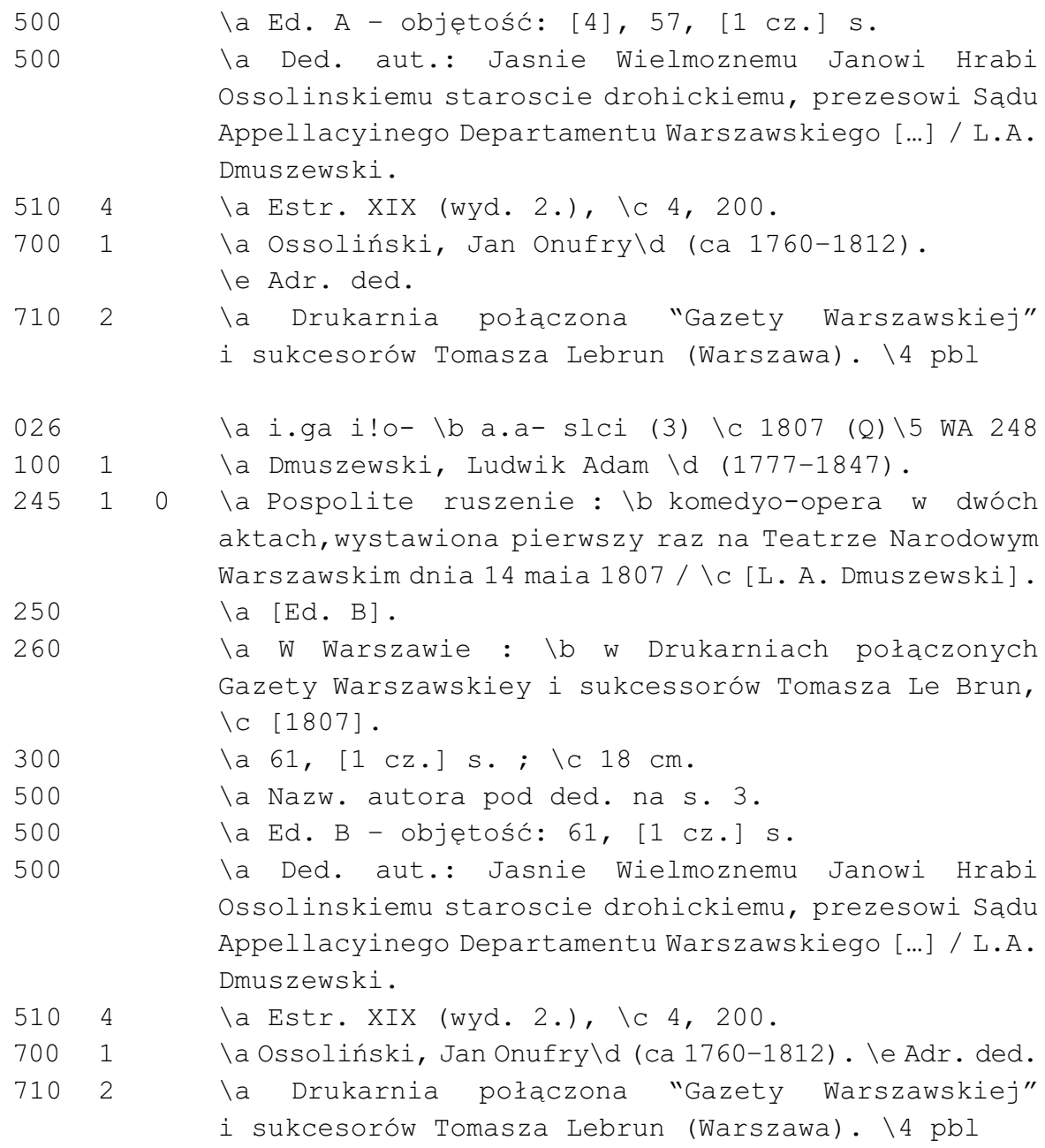

Powyższy przykład nie jest może tak spektakularny jak pierwszy, niemniej i tutaj mamy prawdopodobnie do czynienia $z$ fałszerstwem. Łatwiej je wykryć, bowiem da się ono zauważyć już przy analizie objętości druków. Opis książki sprawił jednak problem K. Estreicherowi. Ponieważ dysponował on opisami dwóch egzemplarzy z tego samego roku i z tym samym adresem wydawniczym, uznał prawdopodobnie, że w zeszytach rejestracyjnych znajduje się błąd, i przedstawił jeden z druków jako anonim typograficzny. Karol Estreicher (wnuk) naprawił błąd dziadka poprzez szczegółowe odpisanie adresu wydawniczego oraz objętości (wskazał w obu wydaniach 3 nieliczbowane strony czyste). Na wszelki wypadek postawił jednak pytanie o istnienie 61-stronicowej edycji bez 
miejsca i roku wydania. W „Nowym Korbucie” i Dawnych pisarzach polskich powielono informacje $\mathrm{z}$ drugiego wydania Bibliografii polskiej.

Gdy K. Estreicher publikował pierwszy tom dzieła swojego życia, zapewne nie podejrzewał nawet, że ponad sto lat później będzie to ciagle podstawowa pomoc dla księgarzy i bibliotekarzy. Tymczasem księgarze zmienili się w antykwariuszy, a bibliotekarze - w katalogerów. Nie ujmując niczego historycznemu znaczeniu i praktycznej użyteczności $B i$ bliografii, trzeba jednak obecnie spojrzeć na nią krytycznie, gdyż nowe zadania stojące przed badaczami książki XIX w. wymagają nowych rozwiązań. Autor miał zresztą świadomość niedoskonałości swojego dzieła i jego licznych braków: ,nie ogarnąłem całego materiału i nie wattpię, że następni badacze po mnie wynajdą jakie kilkadziesiąt tysięcy druków nie zarejestrowanych przeze mnie" ${ }^{22}$. Ale pomimo tego „Bibliografia polska $X I X$ wieku dla tego, kto umie ją czytać, mówi, że wiek XIX w Polsce to jakby drugi złoty wiek naszej kultury" ${ }^{23}$. Niestety, kolejne pokolenia bibliotekarzy wniosły niewiele w udoskonalenie metod rejestracji i opisu druków XIX wieku. Stworzenie w niektórych instytucjach działów książki dziewiętnastowiecznej nie przełożyło się na przygotowanie rozwiązań systemowych. O ile w przypadku starych druków obok Bibliografii polskiej powstało wiele publikacji uzupełniających stan wiedzy, w postaci choćby bibliografii specjalnych (podmiotowych - autorów i drukarzy) i katalogów bibliotecznych, o tyle w przypadku druków dziewiętnastowiecznych ciagle jesteśmy skazani na powielanie opracowanego przez K. Estreichera materiału. Praktyka naukowa księgoznawców (Kazimierza Piekarskiego, Alodii Kaweckiej-Gryczowej, Kazimierza Budzyka, Tadeusza Mikulskiego i innych) pokazuje, że nie da się tworzyć historii piśmiennictwa bez prymarnych badań nad książką. Tylko zgromadzenie materiału podstawowego, dokładna jego analiza, wyciagnięcie wniosków i dopełnienie ich wiedzą wydobyta z archiwów pozwala postawić właściwe pytania o znaczenie książki dla kultury polskiej XIX wieku. To z kolei rodzi konieczność namysłu nad podstawami i stanem naszej dzisiejszej wiedzy o wydawnictwach, bibliotekach i książce XIX stulecia. Owo ważne i dotychczas w tak niewielkim stopniu rozpoznane zagadnienie nie jest dzisiaj w pełni oświetlone, bowiem tak naprawdę nie zdajemy sobie sprawy z licznych kwestii, z którymi przyjdzie nam się jeszcze zmierzyć w badaniach nad książką XIX stulecia. Na te odpowiedzi przyjdzie nam długo poczekać. Jednak mam pewność, że podstawę tych badań powinna stanowić książka. Wskazywanie i rozwiązywanie

${ }^{22}$ K. Estreicher, Bibliografia polska XIX stulecia, cz. 1, t. 1, s. XIII

${ }^{23} \mathrm{~K}$. Estreicher, Bibliografia polska XIX stulecia, wyd. II, t. 1, s. LI. 
różnorodnych problemów przełoży się w końcu na ustalenia dotyczące działalności i siły produkcyjnej warsztatów typograficznych funkcjonujących na ziemiach polskich w XIX wieku. Przyczyni się do wykrycia powiązań między drukarzami (częste sprzedaże całych oficyn lub zasobu typograficznego), odsłoni stosunki zawodowe w obrębie tej grupy, pomoże w poznaniu uwarunkowań gospodarczych i dostarczy bogatego materiału historykowi literatury. Gotowe sposoby przezwyciężenia trudności mamy na wyciagnięcie ręki, wystarczy korzystać z doświadczeń specjalistów od starej książki.

We wstępie do drugiego wydania Bibliografii polskiej K. Estreicher wyraził nadzieję, że obudzi ono zrozumienie dla problemów książki XIX w. Dotychczas nie doczekaliśmy się ukończenia drugiego wydania ani zmian w nastawieniu do książek dziewiętnastowiecznych. Dlatego istotne wydaje się łączenie wysiłku osób, którym nieobojętny jest los książki tego okresu, i przywrócenie jej właściwego miejsca - najpierw w bibliotekach, a później w kulturze.

\section{Streszczenie}

\section{Rola i znaczenie opisu formalnego druku dla badań księgoznawczych nad ksiażką literacką pierwszej połowy XIX wieku}

W opracowaniu formalnym druków XIX w., autor postuluje konieczność odejścia od schematycznych metody opisu bibliograficznego (Format MARC 21 rekordu bibliograficznego dla ksiażki) stosowanych w przypadku standaryzowanej książki współczesnej. Obecny system opracowywania bibliotecznego, nastawiony na rejestrację i efektywność nie może przyczynić się do rozwoju naszej wiedzy na temat cech wydawniczych katalogowanych druków.

Na podstawie wydań korsarskich komedii Ludwika Adama Dmuszewskiego (1777-1847) autor udowadnia, że stosowany system opisu nie spełnia nawet tak podstawowej funkcji, jak rozróżnienia wydań. Wskazuje, że w przypadku najstarszych druków XIX wieku, powinno się stosować odpowiednio rozbudowany schemat opisu bibliograficznego, który dawałby możliwość identyfikacji bez koniecznej porównawczej autopsji innych egzemplarzy dzieła. Szczególną uwagę należy przywiązywać do właściwego odpisania tytułu i adresu wydawniczego (w formie gramatycznej występującej na opisywanym dokumencie, a nie w mianowniku jak w przypadku druków współczesnych) oraz opisu zawartości (dedykacji, kolofonu, list subskrybentów i dzieł współwydanych - w szczególności katalogów księgarskich). Autor uważa, że najprostszym rozwiązaniem jest 
zastosowanie przy opisie druków XIX w., niektórych rozwiązań stosowanych w przypadku druków starych (kollacji, położenia sygnatur bądź fingerprintu).

\section{Summary}

\section{The Role and Significance of the Formal Description of the Book in Research on Books from the First Half of the $19^{\text {th }}$ Century}

The author postulates the need of abandoning in the formal description of nineteenth-century books the use of the schematic method and of the MARC 21 record bibliographic format, which was devised for the standard contemporary book, not a historical one. The type of bibliographic description, which is currently in use, is aimed at optimizing registration procedures and effectiveness, but it is barely suitable for facilitating research on the editorial aspects of nineteenth-century prints.

On the instance of pirate prints of the comedies by Ludwik Adam Dmuszewski (1777-1847), Jacek Paulinek demonstrates that the currently used system is helpless even with regard to distinguishing editions, which is the fundamental function of a bibliographic description. He points out that with respect to early nineteenth-century prints, a much more elaborate system of description should be used, one which would enable the user to distinguish editions without the necessity of personal inspection of the copies themselves. In this description, special attention should be paid to the transcription of the title and the data concerning the publishing house, date, and place. These items should be literally copied from the book. More care is also necessary in describing the content of the book (dedication, colophon, subscribers listings, simultaneously published works, and in particular the booksellers catalogues). The author is convinced that the best solution would be to borrow some of the methods used by the cataloguers working on old prints $(16$ th -18 th c.), like the collations, call number positioning, or the fingerprint. 